\title{
Mobile complex atherosclerotic aortic plaque
}

\author{
Rishi Bajaj, Lovely Chhabra, Mihaela Kruger, Deepti Kumar
}

Department of Internal Medicine, Division of Cardiology, Saint Vincent Hospital, University of Massachusetts Medical School, Worcester, Massachusetts, USA

\section{Correspondence to} Dr Lovely Chhabra, lovids@hotmail.com
To cite: Bajaj R, Chhabra L, Kruger $\mathrm{M}$, et al. BMJ Case Rep Published online:

[please include Day Month Year] doi:10.1136/bcr-2013009542

\section{DESCRIPTION}

A 64-year-old man with a history of paroxysmal atrial fibrillation (AF) and transient ischaemic attack was admitted with complaints of palpitations and fatigue. He was found to be having AF with sustained rapid ventricular response. He had failed rate control therapy with calcium channel blockers and antiarrhythmic therapy (dronedarone), and was on dabigatran for anticoagulation. Prior to undergoing direct current cardioversion, he underwent a transoesophageal echocardiogram (TEE) to rule out left atrial appendage (LAA) thrombus which revealed a large, complex atherosclerotic plaque (size $0.5 \mathrm{~cm}$ ) in the aortic arch extending into the descending thoracic aorta with several highly mobile lesions attached to the plaque (largest size $0.96 \mathrm{~cm}$ ) (figures 1 and 2; videos 1 and 2). There was no LAA thrombus and the patient was successfully cardioverted to sinus rhythm and started on simvastatin.

Aortic arch atheroma is a strong risk factor for atheroembolic stroke. Despite antiplatelet therapy, it carries a risk of recurrent strokes, as high as $11 \%$ at 1 year. ${ }^{1}$ In particular, plaques $4 \mathrm{~mm}$ or greater in thickness proximal to the origin of the left subclavian artery are found in one-third of patients with otherwise unexplained stroke. ${ }^{2}$ TEE can provide information regarding plaque composition, mobility, ulceration as well as anatomic relationship of the plaque to the origin of the great vessels with excellent intraobserver and interobserver reproducibility. Treatment with a statin is a reasonable option for patients with aortic arch atheroma to reduce the risk of stroke. $^{3}$ Oral anticoagulation therapy may be considered in stroke patients with aortic arch atheroma $4 \mathrm{~mm}$ or greater to prevent recurrent strokes. ${ }^{4}$

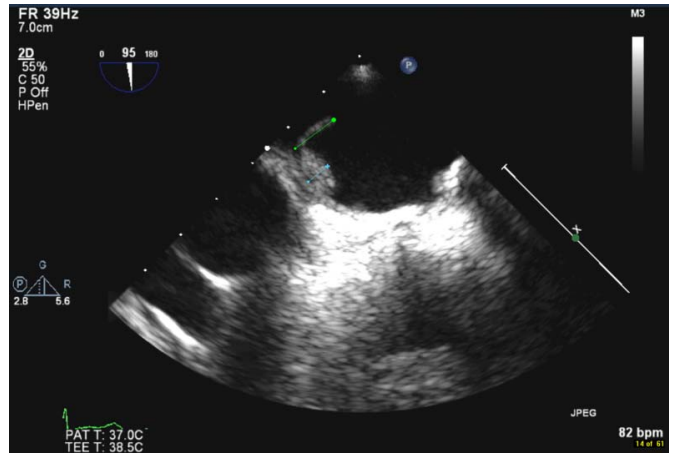

Figure 1 Short-axis view of the aortic arch showing a large complex plaque on transoesophageal echocardiography. One large mobile lesion is seen attached to the plaque.

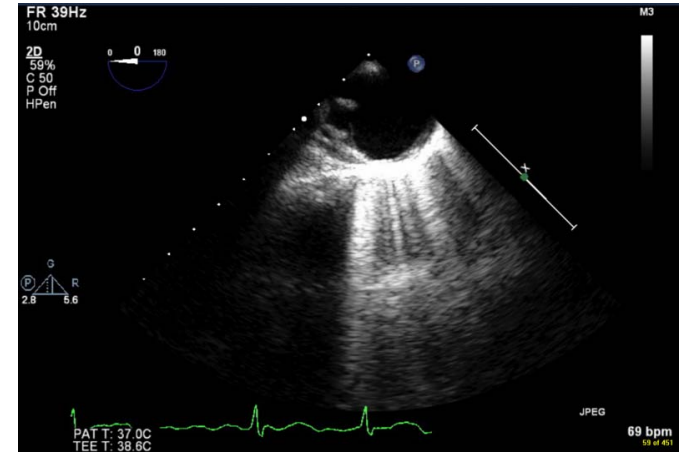

Figure 2 Long-axis view of the aortic arch showing a complex plaque on transoesophageal echocardiography.

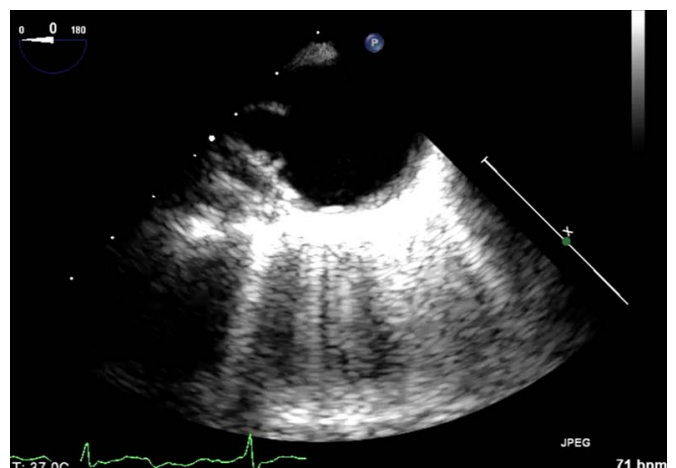

video 1 Short-axis echocardiographic view of the aortic arch showing a large complex plaque on transoesophageal echocardiography. One large mobile atheroma is seen attached to the plaque.

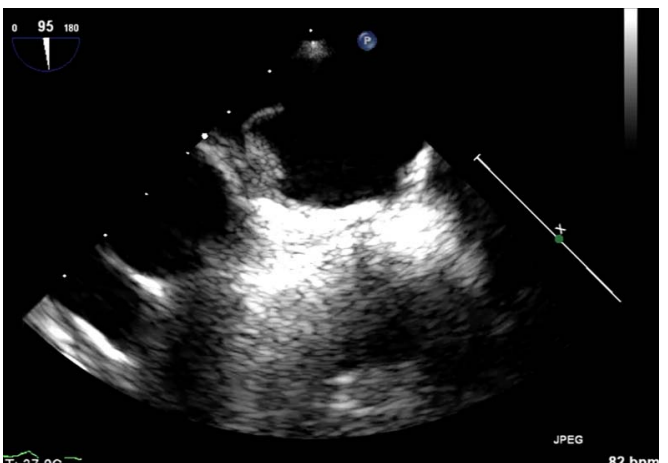

video 2 Long-axis echocardiographic view of the aortic arch showing a large, complex plaque on transoesophageal echocardiography. One large mobile atheroma is seen attached to the plaque. 


\section{Learning points}

- Aortic arch atheroma is a strong risk factor for atheroembolic stroke and peripheral thromboembolism. The risk remains very high despite antiplatelet therapy.

- Oral anticoagulation may be considered in stroke patients with aortic arch atheroma (size $4 \mathrm{~mm}$ or greater), to prevent recurrent strokes.

Competing interests None.

Patient consent Obtained.

Provenance and peer review Not commissioned; externally peer reviewed.

\section{REFERENCES}

1 The French Study of Aortic Plaques in Stroke Group. Atherosclerotic disease of the aortic arch as a risk factor for recurrent ischemic stroke. $N$ Engl I Med 1996;334:1216-21.

2 Khatibzadeh M, Mitusch R, Stierle U, et al. Aortic atherosclerotic plaques as a source of systemic embolism. J Am Coll Cardiol 1996;27:664-9.

3 Tunick PA, Nayar AC, Goodkin GM, et al. Effect of treatment on the incidence of stroke and other emboli in 519 patients with severe thoracic aortic plaque. Am J Cardiol 2002;90:1320-5.

4 Dressler FA, Craig WR, Castello R, et al. Mobile aortic atheroma and systemic emboli: efficacy of anticoagulation and influence of plaque morphology on recurrent stroke. $J$ Am Coll Cardiol 1998;31:134.

Copyright 2013 BMJ Publishing Group. All rights reserved. For permission to reuse any of this content visit http://group.bmj.com/group/rights-licensing/permissions.

BMJ Case Report Fellows may re-use this article for personal use and teaching without any further permission.

Become a Fellow of BMJ Case Reports today and you can:

- Submit as many cases as you like

- Enjoy fast sympathetic peer review and rapid publication of accepted articles

- Access all the published articles

- Re-use any of the published material for personal use and teaching without further permission

For information on Institutional Fellowships contact consortiasales@bmjgroup.com

Visit casereports.bmj.com for more articles like this and to become a Fellow 